\title{
SEPT8 Gene
}

National Cancer Institute

\section{Source}

National Cancer Institute. SEPT8 Gene. NCI Thesaurus. Code C114430.

This gene plays a role in cytoskeletal filament formation. 